\title{
Uczynki miłosierdzia względem ciała i duszy. Historia i praktyka
}

W bulli Misericordiae vultus, zapowiadającej ustanowienie Roku Miłosierdzia, papież Franciszek zawarł następujący apel: „Jest moim gorącym życzeniem, aby chrześcijanie przemyśleli podczas Jubileuszu uczynki miłosierdzia względem ciała i względem ducha”'. Papież zaleca, abyśmy odkryli na nowo uczynki miłosierdzia zarówno względem ciała, jak i duszy, konkretyzując ich wymagania we współczesnych realiach życia społecznego. Odwołując się do ewangelicznego kontekstu, w którym pojawiają się owe uczynki, papież przypomina, że na ich podstawie będziemy sądzeni, dlatego że Chrystus utożsamia się z każdym człowiekiem potrzebującym: „W każdym z tych najmniejszych jest obecny sam Chrystus. Jego ciało staje się znów widoczne jako umęczone, poranione, ubiczowane, niedożywione, w ucieczce"2. Z kolei w liście do Przewodniczego Papieskiej Rady ds. Krzewienia Nowej Ewangelizacji wyraża przekonanie, że za każdym razem, gdy ktoś spełni jeden z tych uczynków w roku jubileuszowym, otrzyma jubileuszowy odpust ${ }^{3}$.

1 Franciszek, Bulla Misericordiae vultus (11 kwietnia 2015), 15.

2 Tamże.

3 Franciszek, List do abp. Rino Fisichella, Przewodniczącego Papieskiej Rady ds. Krzewienia Nowej Ewangelizacji (1 września 2015). 


\section{Uczynki miłosierdzia w tradycji katechetycznej}

Wspomaganie biednych i potrzebujących, jako odpowiedź na wyraźny nakaz realizacji przykazania miłości bliźniego, Kościół uczynił charakterystyczną cechą swojego posłannictwa. To czytelne świadectwo przynależności do Jezusa, który - jak pisał Jan Paweł II:

całą swoją działalnością objawiał, że w świecie, w którym żyjemy, obecna jest miłość. Jest to miłość czynna, miłość, która zwraca się do człowieka, ogarnia wszystko, co składa się na jego człowieczeństwo. Miłość ta w sposób szczególny daje o sobie znać w zetknięciu z cierpieniem, krzywdą, ubóstwem, w zetknięciu z całą historyczną „ludzką kondycją", która na różne sposoby ujawnia ograniczoność i słabość człowieka, zarówno fizyczną, jak i moralną. Właśnie ten sposób i zakres przejawiania się miłości nazywa się w języku biblijnym „miłosierdziem".

Równocześnie z objawieniem ludziom Boga miłosierdzia Chrystus „stawiał wymaganie, aby w życiu swoim kierowali się miłością i miłosierdziem. Wymaganie to stanowi sam rdzeń orędzia mesjańskiego, sam rdzeń etosu Ewangelii”’

Mimo iż wspomaganie ludzi potrzebujących, tych, którzy doświadczyli różnorodnych nieszczęść, nie jest wyłączną domeną chrześcijan ${ }^{6}$, to jednak okazywanie miłosierdzia jest i powinno być znakiem charakterystycznym, dominującą cechą i znamieniem uczniów Chrystusa. Dzieła miłosierdzia różnią się od zwykłego altruizmu, bo są podejmowane z miłości do Chrystusa, jako wyraz posłuszeństwu Jego woli, mają - oprócz doczesnego celu - cel nadprzyrodzony, jakim jest dawanie świadectwa o Bogu i Jego zbawczej miłości do wszystkich ludzi, a także są podejmowane wobec wszystkich, nawet nieprzyjaciół. Wymagają zatem spojrzenia wiary na człowieka, któremu się pomaga, oraz ofiary, poświęcenia i zaparcia się siebie, tak jak to jest wpisane w trud naśladowania Chrystusa. Dlatego słusznie pisze Franciszek, że „dla

4 Jan Paweł II, Encyklika Dives in misericordia (30 listopada 1980), 3.

5 Tamże.

${ }^{6}$ Istnieją świadectwa, że już Egipcjanie praktykowali dzieła miłosierdzia. W jednej z Ksiag zmarłych, które kładziono do grobu wraz z mumiami zmarłych wybitnych faraonów znaleziono następujący napis: „dawał chleb głodnym, wodę pragnącym, ubranie nagim”, por. E. Chenon, Le rôle social de l'Église, Paris 1928, s. 444. J. W. Żelazny, Miłosierdzie u pogan, [w:] Szkoła miłosierdzia świętej Faustyny i Jana Pawła II, red. F. Ślusarczyk, Kraków 2008, s. 84-94. 
Kościoła opcja na rzecz ubogich jest bardziej kategorią teologiczną niż kulturową, socjologiczną, polityczną czy filozoficzną"7.

Spośród dzieł miłosierdzia szczególną rolę zajmują tzw. „uczynki miłosierdzia”, które zostały umieszczone w katechizmie św. Piotra Kanizjusza (15211597) Catechismus maior. Summa doctrinoe $(1555)^{8}$, a także w katechizmie św. Roberta Bellarmina (1542-1621) Explicatio doctrince christiance (1597) 9 . W takiej formie pojawiały się w wielu późniejszych katechizmach narodowych, m.in. w katechizmie Josefa Deharbe'a (180o-1871) Katholischer Katechismus oder Lehrbegriff opublikowanym po raz pierwszy w Ratyzbonie w 1847 roku, a potem zaaprobowanym w całych Niemczech. Na nim wzorowały się polskie katechizmy, kiedy został przetłumaczony na język polski w 1862 roku, m.in. Katechizm opolski ${ }^{10}$. Układ uczynków miłosierdzia przyjmuje także Katechizm Kościoła katolickiego $\mathrm{z} 1992$ roku, w nieco zmodyfikowanej formie ${ }^{11}$, m.in. pominięto „grzeszących upominać”, choć dla Tomasza z Akwinu jest to jeden z najważniejszych uczynków miłosierdzia, bo pozwala uwolnić człowieka od zła grzechu: „Upomnienie bratnie jest wyraźniej (potius) uczynkiem miłości niż leczenie chorób cielesnych, lub uratowanie od biedy drogą wsparcia”"12.

7 Franciszek, Adhortacja Evangelii gaudium (24 listopada 2013), 198.

8 Na jego podstawie powstały dwa inne, jeden dla dzieci: Catechismus minor (1556), drugi dla proboszczów oraz wychowawców: Parvus Catechismus catholicorum (1558).

9 Opera misericordice corporalia: 1) esurientes pascere; 2) potum dare fitientibus; 3) operire nudos; 4) captivos redimere; 5) agrotos invisere; 6) hospitio peregrinos suscipere; 7) mortuos sepelire. Opera misericordice spiritualia: 1) peccantes [w Katechizmie Bellarminiego jest: errantes] corrigere; 2) ignorantes docere; 3) dubitantibus recte consulere; 4) pro salute proximi Deum orare; 5) consolari mostos; 6) ferre patienter injurias; 7) offensam remittere. Łac. peregrinus - oznacza zarówno cudzoziemca, przybysza z daleka, wygnańca, jak też pielgrzyma. Być może dlatego, że dla XVI-wiecznej mentalności bliższe było rozumienie „pielgrzym”, ułatwiało to okazywanie pomocy temu, który był cudzoziemcem. W oryginale greckim użyte jest jednak słowo xe,noj - co oznacza obcego, a raczej człowieka wypędzonego $\mathrm{z}$ własnej ojczyzny, bez praw i opieki.

${ }_{10}$ Katechizm opolski: 1) Głodnych nakarmić; 2) Spragnionych napoić; 3) Nagich przyodziać; 4) Podróżnych w dom przyjąć; 5) Więźniów pocieszać; 6) Chorych nawiedzać; 7) Umarłych pogrzebać. Uczynki co do duszy to: 1) Grzesznych upominać; 2) Nieumiejętnych pouczać; 3) Wątpiącym dobrze radzić; 4) Strapionych pocieszać; 5) Krzywdy cierpliwie znosić; 6) Urazy chętnie darować; 7) Modlić się za żywych i umarłych.

${ }^{11}$ Katechizm Kościoła katolickiego: „Pouczać, radzić, pocieszać, umacniać, jak również przebaczać i krzywdy cierpliwie znosić - to uczynki miłosierdzia co do duszy. Uczynki miłosierdzia co do ciała polegają zwłaszcza na tym, by głodnych nakarmić, bezdomnym dać dach nad głową, nagich przyodziać, chorych i więźniów nawiedzać, umarłych grzebać” (nr 2447).

${ }_{12}$ Św. Tomasz z Akwinu, Summa theologioe, II-II, q. 33, art. 1. 
Natomiast papież Franciszek w swojej bulli przytacza listę tradycyjnych uczynków miłosierdzia ${ }^{13}$.

\section{Geneza i fundamenty biblijne}

Podstawowa reguła chrześcijańskiego życia - wiara w Boga Zbawiciela - realizuje się i weryfikuje w miłości, która musi być czynna, spełniająca się w konkretnych uczynkach realizowanych wobec potrzebującego bliźniego. To jest zasadniczy paradygmat życia chrześcijańskiego, który jasno odczytali uczniowie Chrystusa. Święty Jan pisze: „Jeśliby ktoś posiadał majętność tego świata i widział, że brat jego cierpi niedostatek, a zamknął przed nim swe serce, jak może trwać w nim miłość Boga? Dzieci, nie miłujmy słowem i językiem, ale czynem i prawdą!” $(1 \mathrm{~J} 3,17)$. Podobnie apostoł Jakub: „Jeśli [ ...] brat lub siostra nie mają odzienia lub brak im codziennego chleba, a ktoś $\mathrm{z}$ was powie im: Idźcie w pokoju, ogrzejcie się i najedzcie do syta! - a nie dacie im tego, czego koniecznie potrzebują dla ciała - to na co się to przyda? Tak też i wiara, jeśli nie byłaby połączona z uczynkami, martwa jest sama w sobie" (Jk 2, 15-17). Wiara jest nieustannym działaniem w imię Boże, jest wiarą czynu, która urzeczywistnia się w miłości ${ }^{14}$.

Uczynki miłosierdzia co do ciała mają swoje bezpośrednie źródło w Ewangelii św. Mateusza 25, 31-40. Perykopa mówi o sądzie ostatecznym, podczas którego czyny miłosierdzia okazane potrzebującym są warunkiem zbawienia, nie tylko jako nagroda za szlachetne zachowanie wobec bliźniego, ale jako owoc relacji z Chrystusem, miłości do Niego samego, który zechciał utożsamić się z każdym potrzebującym: „Wszystko, co uczyniliście jednemu z tych najmniejszych, mieście uczynili” (Mt 25, 40) ${ }^{15}$. Identyfikacja z Chrystusem wskazuje na ideę współcierpienia z Nim (por. Rz 8, 17; Ga 2, 19; 2 Tym 2, 11), uczestnictwa w Jego cierpieniach (por. 2 Kor 1, 2; Flp 3, 10; 1 P 4, 13) oraz wyraźnie obecny w całej Ewangelii Mateuszowej obraz Jezusa, który objawia się jako ubogi i cichy Mesjasz, miłosierny i solidarny z tymi, którzy są w nędzy (por. Mt 8, 16nn; 19, 13. 36; 11, 29; 12, 7. 15-21; 14, 14). To konsekwencja kenozy

${ }_{13}$ Por. Franciszek, Bulla Misericordiae vultus, 15.

${ }_{14}$ Por. J. Łach, Wiara bez uczynków jest martwa (Jk 2, 26), [w:] Wiara i życie, red. B. Bejze, Warszawa 1985, s. 62-72.

${ }_{15}$ Por. T. Grzesiak, Uczynki wobec Chrystusa i bliźnich podstawa oceny człowieka na sądzie ostatecznym, [w:] Bądźcie miłosierni jak Ojciec wasz jest miłosierny (Łk 6, 36), red. T. M. Dąbek, Kraków 2002, s. 83-102. 
Chrystusa, który dla nas „stał się ubogi aby nas ubóstwem swym ubogacić” (2 Kor 8, 9). Mateusz używa w odniesieniu do potrzebujących pomocy okre-

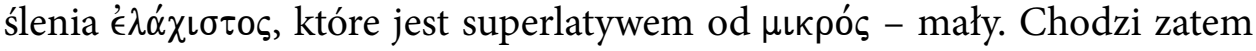
o ludzi najmniejszych, czyli tych, którzy są bez znaczenia w oczach innych, nie mają żadnej powagi w społeczeństwie i pozbawieni są wszelkiej pomocy ze strony ludzi, a nie tylko o tych, którzy w danym momencie cierpią jakiś niedostatek. Pomoc „najmniejszym” wymaga zatem solidarnego utożsamienia się z człowiekiem w jego nędzy, a nie tylko jednostkowego, sporadycznego aktu rzeczowej pomocy.

Wszystkie uczynki wskazane przez Chrystusa (za wyjątkiem odwiedzania więźniów) były w żydowskiej etyce tradycyjnymi aktami sprawiedliwości. W Starym Testamencie prorok Izajasz, wskazując na właściwy wymiar postu, który jest znakiem pokuty i umartwienia, mówi o czynach miłości wobec potrzebujących, wśród których są takie czyny jak: „dzielić swój chleb z głodnym, wprowadzić w dom biednych tułaczy, nagiego, którego ujrzysz przyodziać i nie odwrócić się od współziomków" (Iz 58,7 ). Podobne wezwania do okazania pomocy potrzebującym odnajdujemy w innych pismach: Ez 18, 7; Hi 22, 6n; Syr 7, 34. Natomiast w odniesieniu do więźniów egzegeci wskazują, że dotyczy to chrześcijańskich misjonarzy, wędrujących z głoszeniem Dobrej Nowiny i przez to narażonych na prześladowanie. Los więźniów, o których nikt nie dbał, był bardzo trudny, jeśli nie zaopiekowała się nimi najbliższa rodzina. Dla wędrownych misjonarzy było to tym trudniejsze, że ich rodziny pozostawały daleko, nie mogąc przyjść im z pomocą - stąd konieczność opieki ze strony wspólnoty uczniów ${ }^{16}$. W takim kontekście przypomina o tej powinności św. Paweł, powołując się na swoje własne uwięzienie: „pamiętajcie o uwięzionych, jakbyście byli sami uwięzieni, i o tych, co cierpią, bo i sami jesteście w ciele" (Hbr 13,3).

U Mateusza pojawia się sześć uczynków, zaś siódmy: „umarłych grzebać, dodano w średniowieczu, aby osiągnąć liczbę siedem, symbol doskonałości i pełni. Ten uczynek miłosierdzia pojawia się w powstałej ok. 1164 roku księdze Johannesa Beletha (1135-1182) Rationale divinorum ${ }^{17}$. Nawiązuje do postepowania sprawiedliwego Tobiasza, który kierowany miłością troszczy się o pochówek zmarłych braci, o czym mówi on sam w Księdze Tobiasza: „Dawałem mój chleb głodnym i ubranie nagim. A jeśli widziałem zwłoki któregoś z moich rodaków wyrzucone poza mury Niniwy, grzebałem je" $(1,17)^{18}$.

\footnotetext{
16 Por. A. Paciorek, Ewangelia według świętego Mateusza, cz. 2, Częstochowa 2008, s. 515.

17 Por. J. Beleth, Rationale divinorum, 77: PL 202, 83.

18 Por. I. Noye, Miséricorde, [w:] Dictionnaire de spiritualité, t. 10, cz. 2, kol. 1328-1349.
} 
Święty Tomasz, zastanawiając się, czy właściwe jest włączenie pogrzebu do uczynków miłosierdzia co do ciała, które są formą jałmużny, czyli zaspokojenia braku u potrzebujących, przyznaje, że może się to wydawać niewłaściwe, bo pogrzebanie ciała nie pomaga w niczym zmarłemu. Powołuje się na słowa Chrystusa, że nie należy „bać się tych, którzy zabijają ciało i nic więcej wam zrobić nie mogą" (Mt 25, 28) i dlatego - jak twierdzi - Pan Jezus nie wspomniał o pogrzebie dla zmarłych. Jednak dalej stwierdza, że jałmużna jako zaspokojenie braków bliźniego dotyczy zarówno tych niedostatków, które zachodzą za życia albo po śmierci, i dlatego konkluduje, że „po śmierci należy się jałmużna pod postacią pogrzebania ciała"19.

Było jednak oczywiste dla chrześcijan, że pomoc cierpiącemu ze względu na niedostatek dóbr materialnych nie wyczerpuje wezwania do miłosierdzia, bowiem „nie samym chlebem żyje człowiek” (Mt 4, 4). O ile uczynki co do ciała są wymienione w jednym miejscu, to uczynki co do duszy znajdują swoje uzasadnienie w różnych miejscach Ewangelii, choć nie zawsze są bezpośrednio sformułowane tak jak w zapisie katechetycznym. Orygenes (ok. 185-254) w duchu egzegezy alegorycznej interpretował uczynki miłosierdzia wymienione w Ewangelii Mateusza także jako wezwanie do pomocy w duchowych potrzebach człowieka.

Czy natomiast dobre czyny rozumiemy w sposób prosty i cielesny, czy w sposób duchowy, pewne jest, że czy to tym, czy tamtym sposobem ktoś by spełniał dobry czyn i karmił dusze duchowymi pokarmami, czy to w jakiejkolwiek postaci ktoś by spełnił dobry czyn ze względu na Boga, ten naprawdę Chrystusowi głodnemu i spragnionemu daje jeść i pić. Czy coś czynimy dla świętych, którzy są bogaci w zasługi, a ubodzy w rzeczy, czy to dla jakichkolwiek ludzi, którzy są ubodzy w zasługi, choćby byli bogaci w rzeczy, czy to z jakichkolwiek przyczyn

19 „Pogrzebanie zmarłego w niczym nie pomaga pozbawionemu czucia ciału. I to wyrażają słowa Pana Jezusa, że kto zabije ciało, już nic więcej mu zrobić nie może; dlatego wśród wymienionych dzieł miłosiernych odnoszących się do potrzeb bardziej oczywistych, pominął grzebanie zmarłych. A jednak zmarłą osobę obchodzi ton co będzie zrobione z jej ciałem, bo przecież zależy jej na tym, by żyć w pamięci ludzkiej, i nie chciałaby, by przez niepogrzebanie jej ciała jej cześć doznała ujmy; trzeba też uwzględnić jej przywiązanie do swego ciała za życia, z całym pietyzmem przywiązanie to trzeba uszanować. Dlatego są stawiani za przykład ci ludzie, którzy odznaczyli się troską o grzebanie zmarłych, jak Tobiasz i ci, którzy zatroszczyli się o pogrzebanie ciała Chrystusowego, o czym pisze Augustyn”, św. Tomasz z Akwinu, Summa theologioe, II-II, q. 32 , a. 2 , ad. 1 . 
ktoś by spełniał polecenie Chrystusa - ten Chrystusowi, który sprawiedliwość i prawdę wierzących spożywa i pije, daje jeść i piće ${ }^{20}$.

Na Zachodzie paralelizm między dwiema formami miłosierdzia wprowadził św. Augustyn (354-430) ${ }^{21}$. Tę metodę stosować będą późniejsi autorzy, stopniowo tworząc katalog uczynków miłosierdzia co do duszy. Prawie pełny ich wykaz znajdujemy w popularnym w XII wieku dziełku Gemma animoe $\left(\right.$ Perła duszy) ${ }^{22}$, autorstwa Honoriusza z Autun, zwanego Augustodunensis (1080-1154), benedyktyńskiego mnicha z klasztoru św. Jakuba w Ratyzbonie, prawdopodobnie pochodzącego z Irlandii i będącego uczniem św. Anzelma z Canterbury. Gemma animøe był swego rodzaju małym katechizmem, zawierającym symboliczną wykładnię liturgii (expositio misse), przeznaczonym dla szerokiego kręgu wiernych. Podając katalog uczynków miłosierdzia co do ciała, zestawia je z uczynkami duchowymi (pokarm-praktyka miłości, napójsłowo Boże, odzienie-praktyka cnót, gościnność-duchowe rozmowy, pomoc chorym-spowiedź jako ulga dla duszy, pomoc więźniom-sakrament pokuty jako wyzwolenie z grzechów). Pełny wykaz siedmiu dzieł miłosierdzia co do duszy znajduje się już w dziele Rajmunda z Penyafort (ok. 1175-1275) Summa de ponitentia ${ }^{23}$, a od czasu Tomasza z Akwinu (1255-1274) na stałe znalazły się one w wykładzie teologii na równi z uczynkami miłosierdzia co do ciała ${ }^{24}$.

Oczywiście, wyliczenie 14 uczynków miłosierdzia nie zamyka listy działań, które powinny być podejmowane wobec bliźniego z pobudek chrześcijańskiej miłości, bowiem skala biedy i nieszczęść, jakie spotykały ludzi już w czasach Chrystusa, była o wiele większa, a współcześnie jeszcze się powiększa. Dekret o apostolstwie świeckich Soboru Watykańskiego II, oprócz tradycyjnych uczynków miłosierdzia co do ciała, mówi również o braku mieszkania, lekarstw, pracy, oświaty, środków do prowadzenia życia godnego człowieka. Wszędzie tam „miłość chrześcijańska winna ich szukać i znajdować, troskliwie pocieszać i wspierać" ${ }^{25}$. Ksiądz Stanisław Olejnik wskazywał nie tylko na brak elementarnych środków do życia, ale również na trudności, jakie niesie z sobą życie w zurbanizowanym środowisku: samotność, anonimowość i związane

\footnotetext{
${ }^{20}$ Orygenes, In Matthœum, 72; „Źródła Myśli Teologicznej” 25 (2002) cz. 2, s. 128-130.

${ }^{21}$ Por. św. Augustyn, De moribus Ecclesiae catholicae, 27-28: PL 32, 52-58.

${ }_{22}$ Por. Honoriusza z Autun, Gemma animo, 3, 48: PL 172, 657.

23 Por. Rajmund z Penyafort, Summa de pœnitentia, $3,8$.

${ }^{24}$ Por. św. Tomasz z Akwinu, Summa theologioe, II-II, q. 32, a. 2, 1.

${ }_{25}$ Sobór Watykański II, Dekret o apostolstwie świeckich Apostolicam actuositatem, 8.
} 
z tym zagubienie człowieka, nieradzenie sobie z biurokracją i korzystaniem $\mathrm{z}$ komunikacji ${ }^{26}$. Inni wskazują na takie przestrzenie działań moralnych jak troska o poszanowanie fundamentalnej równości między ludźmi, zniesienie wszelkich form dyskryminacji, zaangażowanie na rzecz pokoju czy szeroko pojęta perspektywa ekologiczna ${ }^{27}$. Możemy do tego dodać działania w sferze ochrony życia: gotowość do adopcji nie tylko dziecka zdrowego, ale także porzuconego czy chorego, dawstwo organów - oddawanie krwi, szpiku kostnego, czy zgoda na pobranie organów po śmierci, długotrwała opieka nad przewlekle chorym, pomoc w wyzwoleniu z nałogów i uzależnień oraz przyjmowanie tych, którzy tworzą ośrodki pomocy dla uzależnionych. W sferze życia społecznego ważne wydaje się umacnianie nadziei u tych, którzy znajdują się w kryzysowym okresie życia pod wpływem zagubienia sensu swojej egzystencji, a także wspieranie tych, którzy walczą o sprawiedliwość i są odważnymi obrońcami prawa Bożego w życiu publicznym.

\section{Świadectwo Ojców Kościoła}

Ewangeliczne wezwanie do okazywania pomocy było podejmowane i realizowane od samego początku życia Kościoła, co widać już w listach nowotestamentalnych (por. Dz 4, $32-5,1$ ). W czasie niedzielnych spotkań organizowane są składki, czy to sporadyczne, czy też miesięczne (stipes) ${ }^{28}$, lub zbierane są dary rzeczowe dla potrzebujących. Poświadczają to także pierwsze chrześcijańskie pisma, jak Didache ${ }^{29}$ czy Pasterz Hermasa, a apologeci widzą w uczynkach miłosierdzia swoisty dowód wiarygodności nadprzyrodzonego wymiaru ewangelicznego orędzia ${ }^{30}$. Pomoc jest okazywana nawet wtedy, kiedy istnieje wątpliwość, czy proszący nie czyni tego z niewłaściwych pobudek:

${ }^{26}$ Por. S. Olejnik, Dar, wezwanie, odpowiedź. Teologia moralna, t. 6: Życie osobiste i wspótżycie międzyludzkie, Warszawa 1990, s. 186.

${ }_{27}$ Por. J. A. Sobkowiak, Nowe uczynki miłosierdzia, [w:] Abyśmy się stali synami Bożymi, Warszawa 2011, s. 217-232; T. Ryłko, Bogaci w miłosierdzie, Kraków 1995.

28 Por. Tertulian, Apologeticum, 39, 5-6, „Pisma Ojców Kościoła” 20 (1947), s. 157-158.

29 „Daj każdemu, kto cię prosi, i zwrotu się nie dopominaj, ponieważ Ojciec chce, żebyśmy ze wszystkimi dzielili się naszymi własnymi darami”, 1, 5: „Pisma Starochrześcijańskich Pisarzy” 45 (1990), s. 57; „Nie odwracaj się od potrzebującego, lecz dziel się wszystkim z bratem twoim, a nie mów, że jest to twoja własność; jeśli bowiem macie wspólny udział w nieśmiertelności, tym bardziej powinniście go mieć w dobrach doczesnych”, 4, 8, tamże, s. 59.

${ }^{30}$ "Zamożny hojnie wspiera ubogiego, a gdy widzą przybysza wprowadzają go do swego domu i cieszą się z niego jak z prawdziwego brata”, Arystydes z Aten, Apologia, 15. 4-6, „Biblioteka 
Dawaj wszystkim, gdyż Bóg chce, abyśmy wszystkim rozdawali Jego własne dary. Ci, którzy brali, zdadzą sprawę Bogu, dlaczego wzięli i w jakim celu brali. Ci, którzy brali, bo byli w potrzebie, nie będą sądzeni, lecz ci, którzy oszukiwali po to, aby brać poniosą karę ${ }^{31}$.

Okazywanie pomocy było podstawowym obowiązkiem chrześcijan, bardzo stanowczo przypominanym przez wszystkich ojców Kościoła ${ }^{32}$. Nieudzielenie pomocy potrzebującemu jest nie tylko brakiem miłości, ale wręcz naruszeniem sprawiedliwości ${ }^{33}$, dlatego że znajdujący się w pilnej potrzebie ma prawo do dóbr, które my posiadamy. Odmówienie pomocy jest aktem kradzieży, a nawet zabójstwa. Przytoczmy kilka świadectw. Święty Bazyli pisze:

Do łaknącego należy chleb, który ty zatrzymujesz; do nagiego szata, którą ty chowasz w skrzyni; do bosego obuwie, które u ciebie pleśnieje; do potrzebującego należą pieniądze, któreś ty zachował. Toteż krzywdzisz tylu, iluś mógł obdarzyćc ${ }^{34}$.

Podobnie św. Jan Chryzostom: „Niedopuszczanie ubogich do udziału w swych własnych dobrach oznacza kradzież i odbieranie życia. Nie nasze są dobra, które posiadamy - należą one do ubogich”35, św. Augustyn: „Dobra zbyteczne bogatych są dobrami koniecznymi ubogich. Cudze rzeczy posiada, kto posiada rzeczy zbyteczne"36, a św. Ambroży zachęca do jałmużny nawet wtedy, jeśli wymaga to poświęcenia: „aby w miarę możliwości, a niekiedy przez

Ojców Kościoła” 24 (2004), s. 145. „Ci, którzy są zamożni i chcą, każdy według własnej woli daje to, co chce, a wszystko, co się zbierze, składa się przełożonemu. On zaś wspomaga sieroty, wdowy, chorych lub z innej przyczyny cierpiących niedostatek, więźniów, obcych, gości, krótko mówiąc, wszystkich potrzebujących bez wyjątku", św. Justyn Męczennik, Apologia, I, 67, [w:] tamże, s. 265.

${ }_{31}$ Hermas, Pasterz, Mandatum 2, 4-5, „Pisma Starochrześcijańskich Pisarzy” 45 (1990), s. 154.

${ }^{32}$ Benedykt xvi pisze, że „działalność charytatywna [Kościoła] utwierdziła się jako jeden z istotnych jego sektorów, obok udzielania Sakramentów i głoszenia Słowa. [...] należy do jego istoty w równej mierze, jak posługa Sakramentów i głoszenie Ewangelii”, Encyklika Deus caritas est (25 grudnia 2005), 22.

33 „Gdy dajemy ubogim rzeczy konieczne, nie czynimy wobec nich ofiary osobistej, ale oddajemy im to, co należy do nich; spłacamy raczej powinność sprawiedliwości, niż wypełniamy dzieła miłosierdzia”, św. Grzegorz Wielki, Regula pastoralis, III, 21: PL 77, 87.

34 Św. Bazyli, Homilia super Lucam 12, 18, 7: PG 31, 278, [w:] św. Bazyli Wielki, Wybór homilij i kazań, przeł. T. Sinko, Kraków 1947, s. 69.

35 Św. Jan Chryzostom, In Lazarum, 1, 6: PG 48, $992 \mathrm{~d}$.

36 Św. Augustyn, Ennaratio in Ps. 147, 12: PL 37, 1922: „Pisma Starochrześcijańskich Pisarzy” 42/1 (1986), s. 349 . 
poniesienie jeszcze większych ofiar zaradzić nędzy bliźnich. Lepiej bowiem dawać dowody uczuć litości, znosić nawet nienawiść, niż okazać się nieludzkim” ${ }^{37}$, w przeciwnym bowiem razie: „Czyż Pan kiedyś nie powie: Dlaczego pozwoliłeś, żeby tylu ubogich umarło z głodu?"38. Święty Cyprian poświęca praktykowaniu miłosierdzia oddzielny traktat De opere et eleemosynis ${ }^{39}$. Święty Grzegorz Wielki nie tylko nakazuje dzielić się dobrami materialnym, ale przypomina także o obowiązku korzystania z posiadanych talentów, w celu przyjścia z pomocą potrzebującym, w przeciwnym wypadku jest to grzech zaniedbania:

Kto więc ma rozum, niech pilnie uważa, aby nie milczał, kto posiada znaczny majątek, niechaj czuwa, aby nie był gnuśny w okazywaniu miłosierdzia, kto ma jakiś zawód, niech bardzo się stara, żeby i bliźni z tego korzystał i wraz z nim podzielał pożytek. Mogąc wstawiać się u bogatego, niech się lęka, żeby go nie uznać za winnego zatrzymania talentu, jeśli nie przemawia do niego za ubogimi ${ }^{40}$.

Nie można również zapominać o tych biednych, którzy wprawdzie posiadają dobra materialne, ale brak im życia duchowego. Święty Jan Chryzostom obrazowo to przedstawia, dokonując porównania do niedostatków materialnych:

W Kościele są nie tylko ubodzy w sensie materialnym, nie tylko tacy, których głodne jest ciało, albo fizycznie pozbawienie są dachu nad głową. Są również ubodzy duchowo: tacy, którym brak pokarmu sprawiedliwości i napoju poznania Boga, którzy nie mają szaty Chrystusa [...]. Są cudzoziemcy, których serce nie

37 Św. Ambroży, De officiis, II, 28, 136, wyd. pol. Obowiązki duchownych, przeł. K. Abgarowicz, Warszawa 1967, s. 157.

${ }_{38}$ Tamże, II, 28, 137, wyd. pol. Obowiązki duchownych, dz. cyt., s. 158. Z drugiej strony Ambroży przestrzega przed taką dobroczynnością, która może zaszkodzić proszącemu o pomoc. Nie można dawać pieniędzy, jeśli mają one służyć złemu celowi. „Szlachetną więc rzeczą jest życzliwość i obdarowywanie kogoś w tej myśli, aby mu pomóc, a nie zaszkodzić. Bo jeślibyś uważał za stosowne dać pieniądze rozpustnikowi na wyuzdaną rozpustę lub cudzołożnikowi na okupienie cudzołóstwa, nie byłoby to dobroczynnością, gdyż brakowałoby tu życzliwości. Byłoby to połączone ze szkodą bliźniego, nie z pożytkiem, jeślibyś np. dał pieniądze takiemu, który knułby spisek przeciw ojczyźnie lub chciałby twoim kosztem gromadzić ludzi nikczemnych do walki z Kościołem”, tamże, I, 30, 144, wyd. pol. Obowiązki duchownych, dz. cyt., s. 70.

39 Por. św. Cyprian, De opere et eleemosynis, I, 30-34: PL 4, 602-622.

40 Św. Grzegorz Wielki, Homilia 9 in Evangelium, 7: PL 76, 1109, „Pisma Starochrześcijańskich Pisarzy" 3 (1969), s. 6o-61. 
ma swego mieszkania, których odwaga jest słaba i zawodna, duchowi ślepcy, głusi w swym nieposłuszeństwie; ludzie którzy cierpią na różne choroby duchowe i są tak chorzy, że dreszczem ich przejmuje widok każdego duchowego pokarmu ${ }^{41}$.

Szczególna wrażliwość na ubogich i okazywanie im pomocy pozostają priorytetem i jednym z charakterystycznych znamion ucznia Chrystusa także wtedy, kiedy wraz z rozwojem życia chrześcijańskiego pojawiają się rozwinięte formy życia wspólnotowego. Widać to np. we wczesnych regułach monastycznych, dla których życie kontemplacyjne jest podstawowym powołaniem ${ }^{42}$. Nowością jest wprowadzenie pewnych reguł takiej działalności. Nie może się nią zajmować każdy mnich, ale należy ono do zadań przełożonego lub tego, komu powierzono to zadanie ${ }^{43}$. Spełnianie uczynków miłosierdzia i jałmużny powinno być roztropne, tak, aby nie wspierać oszustów czy fałszywych gości ${ }^{44}$ oraz by nie zakłócało to kontemplacyjnego charakteru wspólnoty ${ }^{45}$.

Konieczność wspierania biednych można podsumować słowami św. Jana Chryzostoma: „Bez dziewictwa można oglądać królestwo niebieskie, a bez jałmużny jest to niemożliwe. Ona bowiem należy do nieodzownych rzeczy, które podtrzymują wszystko" ${ }^{46}$.

${ }^{41}$ Św. Jan Chryzostom, Opus imperfectum in Matth., 54: PG 56, 946.

42 „Biedacy i pielgrzymi niech będą przyjęci z wyjątkową troską i uwagą, ponieważ szczególnie w nich przyjmuje się Chrystusa”, św. Benedykt, Reguła, 53, 15, „Sources Chrétiennes” 182 (1972), s. 614 .

43 „Czy chodzi o nagiego, czy też o złego, to znaczy - czy ma prawdziwą konieczność, czy też jest oszustem, czy wreszcie chodzi o jakikolwiek inny przypadek, zostało już raz powiedziane, że rozdawanie i otrzymywanie nie leży w gestii wszystkich, lecz jest funkcją tylko tego, kto ma zadanie dokonywać tego rodzaju dystrybucji ze wszelką mądrością i przezornością", św. Bazyli, Asceticon parvum (versio Rufini), 186, 1-3: PL 103, 548CD.

44 „Przyjmijcie każdego, kto przychodzi w imię Pana. Później wypróbujcie go i poznajcie, potraficie bowiem odróżnić prawą rękę od lewej. Jeśli przybysz jest tylko przejazdem, pomóżcie mu na ile was stać, a niech nie zostanie u was dłużej niż dwa lub trzy dni, gdy konieczne. Jeśli zaś chce u was osiąść, a ma jakiś zawód, niech pracuje, by się wyżywić. Jeśli zaś nie ma żadnego zawodu, zadbajcie rozsądnie o to, by chrześcijanin nie żył wśród swoich w bezczynności. Gdyby zaś nie chciał tego uczynić, znaczyłoby to, że kupczy Chrystusem. Strzeżcie się takich ludzi”, Didache, 12, „Pisma Starochrześcijańskich Pisarzy” 45, s. 63.

45 Por. B. Degórski, Uczynki miłosierdzia $w$ świetle starożytnych reguł mniszych, „Vox Patrum” 1996, z. 30-31, s. 259-274.

${ }^{46}$ Św. Jan Chryzostom, Homilie na Ewangelię Mateusza, 47, 4, „Źródła Myśli Teologicznej” 18 (2000), s. 74. 


\section{Modele realizacji uczynków miłosierdzia}

Spełnianie dzieł miłosierdzia stało się powszechnym elementem chrześcijańskiej tożsamości. W sposobie ich praktykowania na przestrzeni wieków, a zwłaszcza w czasach współczesnych, można dostrzec różne podejścia lub akcentowanie odmiennych aspektów, dotyczących bądź to motywów czynienia miłosierdzia, bądź celów, jakie zamierza się przez nie osiągnąć.

\section{Uczynki miłosierdzia jako jałmużna}

Dla Tomasza z Akwinu chrześcijańska miłość realizuje się w praktyce poprzez cnotę miłosierdzia, pobudzającą do uczynków, których zasadniczym celem jest pomoc cierpiącemu niedostatek. Uczynki miłosierdzia traktuje jako jałmużnę definiowaną jako „dzieło dania ze współczucia czegoś potrzebującemu ze względu na Boga" (opus quo datur aliquid indigenti ex compassione propter Deum $)^{47}$. Celem jałmużny jest zaspokojenie różnych braków u bliźniego, te zaś mogą być dwojakiego rodzaju: „zachodzą albo w duszy, tym służą jałmużny duchowe, albo w ciele, tym służą jałmużny cielesne" ${ }^{48}$. Tomasz, komentując zawartą w uczynkach powinność moralną, zwraca uwagę na pewne zależności. Po pierwsze twierdzi, że jałmużny duchowe „stoją wyżej” (eminentior ac prestantior) i to z trzech powodów: 1) to, co jest w nich udzielane, jest wyższego rzędu (nobilius est); 2) dusza, którą wspomagamy przez jałmużnę duchową, jest ważniejsza niż ciało; 3) uczynki duchowe ze względu na swoją naturę są wyższego rzędu ${ }^{49}$. Nie oznacza to jednak lekceważenia uczynków co do ciała, bowiem jak stwierdza Tomasz, są sytuacje, w których najpierw trzeba zadbać o podstawowe dobro człowieka, zanim zaoferuje się mu dobro wyższego rzędu. Powołuje się w tym na słowa Arystotelesa: „potrzebującemu należy dać, a nie z nim filozofować”, choć filozofia jest czymś wyższym. Mogą się jednak zdarzyć sytuacje, w których proszącemu o materialną pomoc odmawiamy, ale w taki sposób, że odmowa staje się dla niego swoistym napomnieniem, a więc uczynkiem miłosierdzia co do duszy. W tym Tomasz odwołuje się do św. Augustyna: „dawać należy tak, by to nie szkodziło ani tobie ani jemu; a jeśli odmawiasz mu tego, o co cię prosi, wytłumacz mu powody by od ciebie nie odszedł bez niczego, a może

\footnotetext{
47 Św. Tomasz z Akwinu, Summa theologio, II-II, q. 32, a. 1.

48 Tamże, II-II, q. 32, a. 2.

49 Tamże, II-II, q. 32, a. 3.
} 
niekiedy dasz coś lepszego, gdy tego, który niesłusznie prosi, upomnieniem doprowadzisz do poprawy"50.

Tomasz stawia pytanie, czy jałmużna jest działaniem nakazanym przez przykazanie, a więc czy posiada rangę ścisłej powinności. Ponieważ jałmużna jest integralną częścią miłości wobec bliźniego, do której jesteśmy zobowiązani przykazaniem, a miłość ta musi być czynna i nie może pozostawać na poziomie jedynie emocjonalnego współczucia czy słownych deklaracji, wobec tego również i uczynki miłosierdzia są pośrednio objęte przykazaniem. Jest to jednak przykazanie $\mathrm{w}$ ramach realizacji cnoty miłości, a cnota $\mathrm{z}$ natury rzeczy wymaga działania zgodnego z prawym rozumem (recta ratio), tak aby nie zamieniła się w działanie jej przeciwne. Dlatego Tomasz precyzuje warunki realizacji jałmużny w zależności od osoby dającej, jak też tej, która znajduje się w potrzebie:

przykazanie nakazuje dawanie jałmużny z tego, co zbywa, oraz danie temu, którego potrzeba jest koniecznością. Poza tymi dwoma warunkami, dawanie jałmużny jest zalecone radami, podobnie jak wszystkie inne uczynki „lepsze”

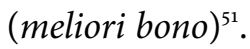

Są więc dwa elementy warunkujące powinność moralną w dawaniu jałmużny.

\section{Posiadane dobra}

Akwinata odwołuje się do kategorii tzw. „dóbr zbywających” (bona superflua) - za tekstem Ewangelii św. Łukasza: „dawajcie jałmużnę z tego, co zbywa” $(Ł k \text { 11, 41 })^{52}$. Dobrami zbytecznymi określa się te dobra, które pozostają właścicielowi po zaspokojeniu własnych, słusznych i godziwych potrzeb. Jeśli ktoś posiada takie dobra, jest zobowiązany do okazania pomocy potrzebującemu. Tomaszowi nie chodzi o to, że posiadający mają cały swój majątek przekazać

50 Św. Augustyn, De sermo Domine in Monte, I, 20. PL 34, 1264, „Pisma Starochrześcijańskich Pisarzy" 48 (1989), s. 66.

${ }_{51}$ Św. Tomasz z Akwinu, Summa theologioe, II-II, q. 32, a. 5.

${ }^{52}$ W tekście Wulgaty, którą posługiwał się Tomasz, znajduje się następujące sformułowanie tego zdania: „Verumtamen quod superest date elemosynem et ecce omnia munda sunt vobis”, natomiast w Nowej Wulgacie wydanej w 1979 r. tłumaczenie zostało zmodyfikowane: „Verumtamen, quae insunt, date eleemosynam; et ecce omnia munda sunt vobis”, a w Biblii Tysiąclecia brzmi następująco: „Raczej dajcie to, co jest wewnątrz, na jałmużnę, a zaraz wszystko będzie dla was czyste". Tłumaczenia te, zgodnie $z$ oryginałem greckim, wskazują na ofiarę płynącą $z$ wewnątrz człowieka, czyli z szerszej woli. 
na zaspokojenie potrzeb biednych, ale wskazuje na moralny charakter takiego działania, który jest poważnym wymaganiem ${ }^{53}$. Jest natomiast przekonany, że z rzeczy koniecznych, w najściślejszym tego znaczeniu, czyli takich, bez których dana rzecz nie może istnieć, nie można dawać jałmużny, czyli nie można odmówić sobie i tym, kogo mamy na utrzymaniu, środków potrzebnych do życia, chyba że zachodzi szczególna sytuacja ze względu na dobro wspólne (społeczeństwa czy Kościoła) ${ }^{54}$.

To rozwiązanie zostało zaakceptowane przez Magisterium, choć wskazywano, że sposób jego realizacji może być różny ${ }^{55}$. Pius xI wskazał na sposoby wykonania owego obowiązku. Należą do nich: jałmużna (wspieranie poszczególnych potrzebujących), dobroczynność (popieranie dzieł charytatywnych lub dzieł opieki społecznej) oraz wspaniałomyślność (wspieranie dzieł wspierających rozwój cywilizacyjny i kulturowy, budowa szpitali i szkół, a także tworzenie nowych miejsc pracy). Późniejsze nauczanie Kościoła, nie negując Tomaszowego rozwiązania, stopniowo poszerzało rozumienie owej pomocy. Sobór Watykański II, odnosząc się do bona superflua, wskazuje, że chrześcijanin wobec dramatu ubóstwa winien pomagać „nie tylko z tego, co nam zbywa, lecz także $\mathrm{z}$ tego, co niezbędne" 56 . Do tego nauczania odwołuje się Jan Paweł II, który był przekonany, że model dobroczynności zawarty w zasadzie bona superflua nie jest absolutny i może, a czasem powinien być przekraczany. W Orędziu na Wielki Post 1983 roku, wspominając o różnych formach dobroczynności, mówi o ofiarach „pochodzących z tego, co nam zbywa, a czasami i z tego, co nam samym potrzebne" 57 . W innym Orędziu na Wielki Post formułuje jeszcze bardziej zdecydowane wezwanie:

53 Por. C. Strzeszewski, „Bona superflua” w etyce społecznej św. Tomasza z Akwinu, „Roczniki Filozoficzne" 8 (1960) z. 2, s. 53-59.

54 Św. Tomasz z Akwinu, Summa theologioe, II-II, q. 32, a. 6.

55 „Nasuwa się tu sprawa wolnych dochodów (reditus liberi), to jest tych, które człowiekowi zostają po opędzeniu potrzeb związanych z utrzymaniem się na stopie przyzwoitości i odpowiednio do zajmowanego stanowiska. Człowiek nie ma zupełnej swobody w rozporządzaniu nimi. Przeciwnie, zarówno Pismo Święte, jak i Ojcowie Kościoła bardzo stanowczo uczą, że na bogaczach spoczywa poważny obowiązek praktykowania jałmużny, dobroczynności i wspaniałomyślności”, Pius XI, Quadragesimo anno, 50.

${ }_{56}$ Sobór Watykański II, Konstytucja duszpasterska o Kościele w świecie współczesnym Gaudium et spes, 88 .

57 Jan Paweł II, Orędzie na Wielki Post 1983. 
W trudnym okresie, jaki obecnie przeżywamy, nie możemy się już ograniczać do dawania $\mathrm{z}$ tego, co nam zbywa: trzeba zmienić wzory postępowania i konsumpcji, aby udostępnić innym również rzeczy nam potrzebne i zachowywać dla siebie tylko to, co niezbędne, ażeby wszystkim zapewnić godziwe warunki życia. Umartwiajmy nasze pragnienie posiadania, często nieumiarkowane, aby dać bliźniemu to, czego pilnie potrzebuje ${ }^{58}$.

W dalszej części Akwinata roztrząsa także cały szereg szczegółowych kwestii moralnych zawiązanych $\mathrm{z}$ jałmużną: czy można dawać jałmużnę z nieuczciwego zysku ${ }^{59}$, czy osoby mogą dysponować majątkiem nie swoim tylko przez siebie zarządzanym, czy można wydawać dużo itp.

\section{Rodzaj i stopień potrzeby}

Biorąc pod uwagę fakt, że nie wszystkim, którzy doświadczają niedostatków, można jednakowo pomóc, scholastyczna teologia moralna, opierając się na Tomaszowej refleksji, wypracowała klasyfikację potrzeb, jakich może doświadczać człowiek. Najpierw, odnośnie do rodzaju potrzeb, mówiono o dobrach potrzebnych do życia (bona necessaria vitoe), dalej - o dobrach koniecznych dla tego, aby utrzymać się na poziomie pewnego stanu, to znaczy takich, bez których człowiek podupada społecznie (bona necessaria statui), wreszcie o dobrach potrzebnych do utrzymania stopy życiowej właściwej dla swojej pozycji społecznej czy zawodowej (bona necessaria decentice status).

Z drugiej zaś strony określano stopień zachodzącej potrzeby. Rozróżniano: 1) potrzebę skrajną (necessitas extrema), która ma miejsce wówczas, gdy człowiek znajduje się w niebezpieczeństwie śmierci fizycznej lub duchowej w wyniku braku koniecznych do życia dóbr; 2) potrzebę poważną (necessitas gravis), zachodzącą wówczas, gdy ktoś bez pomocy drugiego nie może uniknąć poważnej szkody fizycznej lub duchowej; 3) potrzebę zwyczajną (necessitas communis) - gdy ktoś znajduje się pośród pewnych przeciwności, ale jest

${ }^{8}$ Jan Paweł II, Orędzie na Wielki Post 1984, 5.

59 Rozróżnia trzy formy nieprawnie nabytych dóbr: 1) takie, które należą do właściciela i należy je zwrócić (pochodzące z kradzieży czy lichwy); 2) nabyte niesprawiedliwie od dającego niesprawiedliwie (np. świętokupstwo), takie dobra należy dać na jałmużnę;3) dobra nabyte zgodnie z prawem (czy raczej umową), ale za rzecz lub czynność zakazaną (np. prostytucja), wówczas mogą te dobra zatrzymać dla siebie i dawać z tego jałmużnę. Por. św. Tomasz z Akwinu, Summa theologio, II-II, q. 32, a. 7 . 
w stanie o własnych siłach zorganizować sobie pomoc i poradzić sobie w danej sytuacji ${ }^{60}$.

Oczywiście nie można stosować tych rozróżnień mechanicznie, bowiem może się zdarzyć, że to, co dla kogoś jest sytuacją zwyczajnej potrzeby, dla kogoś, kto jest mniej zaradny lub w jakiś sposób mniej przystosowany do funkcjonowania życiowego, może stanowić sytuację poważnej potrzeby. Z drugiej strony trzeba brać pod uwagę różnicę między rzeczywistym ubóstwem a subiektywnym poczuciem bycia ubogim, które pojawia się w wyniku konfrontacji swojego stanu materialnego ze stanem posiadania innych ludzi ${ }^{61}$. Nie bez znaczenia może być także fakt, czy mamy do czynienia z potrzebą bezpośrednio dotykającą bliźniego w dobrach odnoszących się do podstawowych potrzeb człowieka, czy też jest to sytuacja długotrwała. W pierwszym wypadku potrzebna jest natychmiastowa pomoc, w drugim pomoc długotrwała i strukturalna. Ocena w konkretnych przypadkach wymaga nie tylko zaangażowania cnoty roztropności, ale właśnie postawy miłosierdzia, która nie pozwala zbyt rygorystycznie i w sposób nadmiernie zobiektywizowany dokonywać szacunku sytuacji.

Uwzględniając oba te uwarunkowania, Tomasz stwierdza, że w przypadku ludzi, którzy sami żyją skromnie, okazanie pomocy drugiemu nie jest ścisłą powinnością, natomiast dla tych, którzy cieszą się dobrobytem materialnym, ten obowiązek jest poważny, zarazem jednak w sytuacji skrajnej potrzeby, gdy życie ludzkie jest zagrożone, należy pomóc bliźniemu niezależnie od osobistego stanu posiadania.

${ }^{60}$ Por. H. Noldin, Summa theologice moralis, vol. 2: De proeceptis, Insbruck 1955, s. 86-88.

${ }^{61}$ „Należy rozróżnić pomiędzy ubóstwem a poczuciem bycia ubogim. W epoce mocno oddziaływujących na człowieka mediów, mamy często do czynienia z sytuacją, w której ktoś, konfrontując się - głównie za pośrednictwem telewizji - z poziomem życia bardzo bogatych państw i grup społecznych albo z w wyimaginowanym światem reklamy, zaczyna czuć się człowiekiem materialnie ubogim. Przestaje dostrzegać realne problemy konkretnych ludzi obok, nie mówiąc już o rzeczywistej biedzie w wielu innych państwach. Oznacza to, że subiektywne poczucie bycia ubogim nie zawsze odpowiada rzeczywistości, a niekiedy jest po prostu formą frustracji, mającej swoją dodatkową przyczynę w duchowej pustce, czyli braku ewangelicznego ubóstwa duchowego", J. Chrapek, Tylko miłość się liczy... List pasterski biskupa radomskiego na temat biedy i ubóstwa (25 marca 200o), 6, http://mateusz.pl/czytelnia/jch-tylko-milosc.htm (3.11.2015). 
Uczynki miłosierdzia jako owoc mistycznego upodobnienia się do Chrystusa. Święta Faustyna Kowalska

Miłosierdzie jest cnotą, która rodzi się z własnego doświadczenia bycia obdarowanym. To Bóg pierwszy nas umiłował, kiedy byliśmy jeszcze grzesznikami. Przypowieść o niegodziwym słudze, któremu pan wiele darował, także na to wskazuje: „Sługo niegodziwy! Darowałem ci cały ten dług, ponieważ mnie prosiłeś. Czyż więc i ty nie powinieneś był ulitować się nad swoim współsługą, jak ja ulitowałem się nad tobą?" (Mt 18, 32nn).

Chrześcijanin to człowiek, który ma świadomość fundamentalnego obdarowania: obdarowania stworzeniem (własnym istnieniem oraz światem będącym do jego dyspozycji), odkupieniem w Chrystusie, łaską przebaczenia grzechów i obietnicą bycia jak Bóg (por. $1 \mathrm{~J}$ 3, 2). To obdarowanie wydobywa ludzkie istnienie z niebytu, zarówno ontologicznego, jak i moralnego, aż do najwyższego stanu istnienia, jakim jest uczestnictwo w Bożej naturze. Na mocy łaski - czyli miłosiernego obdarowania - człowiek zostaje wyrwany z własnej nędzy i włączony w Boży nurt miłości, dzięki któremu może przynosić owoce miłosierdzia w stosunku do potrzebujących. To mistyczne doświadczenie przeżyła św. Faustyna osobiście, a sam Chrystus objawił jej tajemnicę owej dialektyki nędzy-obdarowania ${ }^{62}$. W czasie jednych ze swoich rekolekcji usłyszała zaskakujące słowa: „Jesteś bardzo nędzną i spodobało Mi się przeprowadzić dzieło miłosierdzia właśnie przez ciebie, która jesteś nędzą samą" ${ }^{\text {"63 }}$.

Chrystus objawia Faustynie trzy formy realizacji miłosierdzia: „Podaję ci trzy sposoby czynienia miłosierdzia bliźnim: pierwszy - czyn, drugi - słowo, trzeci - modlitwa. W tych trzech stopniach zawiera się pełnia miłosierdzia i jest niezbitym dowodem miłości ku Mnie" ${ }^{\prime 4}$. Natomiast sama Faustyna, modląc się o to, aby mogła być całkowicie odbiciem miłosiernego Boga, prosi o przemianę swoich zmysłów oraz członków ciała, aby służyły miłosierdziu: oczy, aby nie sądzić bliźnich pochopnie, lecz by dostrzegać piękno w ich duszach; słuch, aby uszy nie były obojętne na wołanie o pomoc; język, aby nie mówił źle o innych, lecz miał słowa pociechy i przebaczenia; ręce, aby były „pełne dobrych uczynków, bym tylko umiała czynić dobrze bliźnim, na siebie przyjmować cięższe,

62 „Największym skarbem duchowym Siostry Faustyny była świadomość ubóstwa przed Bogiem, dzięki któremu stała się zdolna ofiarować siebie jako hostię całopalną razem z Umiłowanym”, J. Machniak, Miłosierdzie jako styl życia św. Siostry Faustyny Kowalskiej, [w:] Szkoła miłosierdzia świętej Faustyny i Jana Pawła II, dz. cyt., s. 286.

${ }_{3}$ F. Kowalska, Dzienniczek, Kraków-Stockbridge-Rzym 1981, 883, por. także 1182.

${ }_{64}$ Tamże, 742, por. także 163, 1158. 
mozolniejsze prace”; nogi, aby spieszyły pomagać innym, i wreszcie serce, aby współczuło „ze wszystkimi cierpieniami bliźnich”65. Prośba ta wskazuje na chęć wypracowania trwalszych postaw moralnych, czyli cnoty miłosierdzia, tak aby mogła rozpoznawać i podejmować dzieła miłosierdzia zawsze tam, gdzie to jest potrzebne.

Siostra Faustyna żali się Jezusowi, że często jest niezrozumiana bądź że jej intencje, $z$ jakimi podejmuje uczynki miłosierdzia, są źle interpretowane przez innych i z tego powodu jej dobroć jest często nadużywana. Wówczas usłyszała odpowiedź Chrystusa: „To nic, córko Moja, niech cię to nie obchodzi, ty zawsze bądź miłosierna dla wszystkich, a szczególnie dla grzeszników”"66, a ona sama postanawia „obcować szczerze nawet z tymi, o których wiem, że nadużywać będą dobroci mojej" ${ }^{\prime 6}$. Słowa te mogą być wskazówką, jak postępować wobec tych, którzy próbują wykorzystywać naszą postawę dobroci. Trzeba zachować roztropność w czynieniu dzieł miłosierdzia, ale nie przekreślać ich sensowności pod wpływem jednostkowych przykładów nadużycia. Wina moralna jest wtedy zawsze po stronie tego, który dokonuje oszustwa.

\section{Uczynki miłosierdzia jako troska o godność osoby}

Poszczególne uczynki miłosierdzia zaspokajają konkretne potrzeby człowieka, ale jeszcze nie wyczerpują w pełni ewangelicznego wezwania do bycia miłosiernym, tak jak Ojciec jest miłosierny (por. Łk 6, 36). Taka „aktualistyczna interpretacja miłosierdzia” - jak ją nazywa ks. Henryk Wejman, zawężona jedynie do spełnienie konkretnego uczynku, może skutkować upokorzeniem, a nawet przybrać formę wyzysku człowieka ${ }^{68}$. Tymczasem miłosierdzie w istocie swej jest wydarzeniem personalnym, to znaczy uaktywnioną relacją interpersonalną zbudowaną na miłości, która dotyka człowieka w jego godności. Człowiek, któremu brak najbardziej elementarnych rzeczy do życia staje się najbardziej poniżony w swoim człowieczeństwie. W uczynkach miłosierdzia nie chodzi zatem tylko o samą przedmiotową pomoc, nie chodzi o rzeczy, ale przede wszystkim chodzi o osoby, które są zaangażowane w doświadczenie miłosierdzia: udzielanego i przyjmowanego. To jest wymiar miłosierdzia, na który szczególnie zwracał uwagę Jana Paweł II: „Orędzie o miłosierdziu

65 Tamże, 163.

66 Tamże, 1446.

67 Tamże, 163.

${ }_{68}$ Por. H. Wejman, Personalistyczna koncepcja miłosierdzia, „Teologia i Moralność” 2 (2007), S. $210-211$. 
Bożym stanie się pośrednio również orędziem o niepowtarzalnej godności, wartości każdego człowieka. W oczach Bożych każda osoba jest cenna, za każdego Chrystus oddał swoje życie, każdemu Ojciec daje swego Ducha i czyni go bliskim sobie" ${ }^{69}$.

Paradygmat godności osoby dotyczy także sposobu udzielania pomocy, nie może być ona realizowana w ten sposób, aby człowiek czuł się kimś gorszym, nieużytecznym i bezwartościowym, którego egzystencję trzeba zabezpieczyć na minimalnym poziomie wystarczającym do przeżycia. Akty miłosierdzia spełniają swoje zadanie w najpełniejszym sensie wtedy, kiedy wyzwalają w obdarowanym świadomość wartości własnego człowieczeństwa i potencjał, który tkwi w każdym człowieku, mimo brzemienia zła, którego doświadczył. „W swoim właściwym i pełnym kształcie miłosierdzie objawia się jako dowartościowywanie, jako podnoszenie w górę, jako wydobywanie dobra spod wszelkich nawarstwień zła, które jest w świecie i w człowieku"7o. W tym kontekście wspaniałym przykładem są inicjatywy np. wśród bezdomnych, którzy sami okazują pomoc innym.

Takie spojrzenie na uczynek miłosierdzia wymaga również innego podejścia ze strony ofiarującego pomoc. Nie może być ona ze strony ofiarodawcy wyrazem zwykłej litości i współczucia, strachu przed potrzebującym, który może stać się agresywny, uspokojeniem swojego sumienia, ale musi być zawsze działaniem z miłości, czyli wyrażającym zasadniczą postawę akceptacji i przyjęcia drugiego człowieka jako daru. Pozostaje darem dla ofiarującego pomoc, nawet jeśli on sam znajduje się w wielkiej potrzebie i potrzebuje daru. Okazujący pomoc jest $\mathrm{w}$ ten sposób również obdarowany ${ }^{71}$. Zarazem także ten, kto przyjmuje, powinien to czynić ze świadomością, że świadczy dobro dającemu. Ta interakcja w uczynku miłosierdzia przeżywana na poziomie

69 Jan Paweł II, Dar Boży dla naszych czasów, homilia na mszy kanonizacyjnej bł. Faustyny Kowalskiej (3o kwietnia 200o), „L'Osservatore Romano” 6 (2000), s. 26.

70 Jan Paweł II, Encyklika Dives in misericordia, 6. Por. H. Wejman, Jana Pawła II personalistyczna koncepcja miłosierdzia, [w:] Szkoła miłosierdzia świętej Faustyny i Jana Pawła II, dz. cyt., s. 189-214.

${ }^{71}$ „Miłość miłosierna we wzajemnych stosunkach ludzi nigdy nie pozostaje aktem czy też procesem jednostronnym. Nawet w wypadkach, w których wszystko zdawałoby się wskazywać na to, że jedna strona tylko obdarowuje, daje - a druga tylko otrzymuje, bierze - (jak np. w wypadku lekarza, który leczy, nauczyciela, który uczy, rodziców, którzy utrzymują i wychowują swoje dzieci, ofiarodawcy, który świadczy potrzebującym), w istocie rzeczy zawsze również i ta pierwsza strona jest obdarowywana. A w każdym razie także i ten, który daje, może bez trudu odnaleźć siebie w pozycji tego, który otrzymuje, który zostaje obdarowany, który doznaje miłości miłosiernej, owszem, doznaje miłosierdzia”, Jan Paweł II, Encyklika Dives in misericordia, 14. 
obdarowania przez miłość i w miłości sprawia, że „ludzie spotykają się ze sobą w samym tym dobru, jakim jest człowiek z właściwą mu godnością"72.

Pojęcie godności człowieka pozwala zrozumieć, że miłosierdzie jest czymś więcej niż tylko zaspokojeniem wymogów sprawiedliwości, a zarazem że sama sprawiedliwość bez miłosierdzia nie wystarcza. Dzieje się tak dlatego, że w grę wchodzą nie tylko pewne dobra przedmiotowe, które należy właściwe dystrybuować, ale także dobro zasadnicze, jakim jest samo człowieczeństwo człowieka, jego osobowa godność. Dlatego - zgodnie z normą personalistyczną sformułowaną przez Jana Pawła $\mathrm{II}^{73}$ - tylko miłość zapewnia właściwe odniesienie do drugiego człowieka i jej adekwatną realizację w poszczególnych dziełach miłosierdzia.

\section{Uczynki miłosierdzia jako prewencja}

Już w XIX wieku rodził się sprzeciw wobec jałmużny jako sposobu pomocy ludziom potrzebującym. Twierdzono, że jest ona niewystarczająca, a nawet uwłaczająca człowiekowi; stanowi natomiast formę uspokojenia własnego sumienia i odsuwa radykalne rozwiązania, które należy podjąć dla rozwiązania problemu ludzkiej biedy. Postulowano stworzenie nowego porządku prawnego, który zabezpieczałby przed ubóstwem, przynajmniej w najbardziej skrajnej postaci, i pozwoliłby wszystkim sprawiedliwie uczestniczyć w dobrach wypracowanych przez społeczeństwo. Wówczas dzieła miłosierdzia byłyby zbyteczne. W przeszłości - jak zauważa Paul Zulehner - uczynki miłosierdzia pełniły charakter terapeutyczny, gdyż zapewniały bliźnim to, czego im brakowało do godnego życia, leczyły rany powstałe w wyniku biedy i nieszczęścia. Współcześnie postuluje się, by zwrócić uwagę na prewencyjny wymiar uczynków miłosierdzia, których cel polegałby na zapobieganiu takim sytuacjom, w których pojawialiby się ludzie potrzebujący. Tak rozumiane miłosierdzie wymaga działań planowych, strukturalnych i kompleksowych, dlatego oprócz odpowiednio przygotowanych struktur organizacyjnych (stowarzyszenia, fundacje, komitety, okolicznościowe akcje itp.) potrzebne jest zaangażowanie polityczne. Jako model takiego zaangażowania Zulehner podaje wzór nowego „świętego”, którego mógłby kanonizować Kościół za nową działalność charytatywną, i opisuje jego przymioty:

Taki polityczny święty stworzy zubożałym głodującym dostęp do takich środków produkcji, jak rola, ziarno na zasiew i woda; będzie się starał, żeby ludzie

${ }_{72}$ Jan Paweł II, Encyklika Dives in misericordia, 14.

73 Por. Jan Paweł II, Przekroczyć próg nadziei, Lublin 1994, s. 150-151. 
dysponowali dochodami wyższymi niż te, które wystarczają tylko na to, by móc kupić środki żywności. [...] Do jego programu politycznego będzie też należało zwiększenie inwestycji w naukowych badaniach rolniczych, nawadnianiu, budowie lokalnych dróg, zaopatrzeniu w wodę i w oświacie. [...] Nasz polityczny święty będzie zatem doskonałym ekspertem od spraw głodu ${ }^{74}$.

Benedykt XVI przestrzega jednak przed niebezpieczeństwem, jakie kryje się w zbyt idealistycznym postrzeganiu polityki jako jedynego narzędzia zdolnego zaspokoić sprawiedliwość społeczną. Przypomina, za całą tradycją społecznego nauczania Kościoła, o istnieniu dwu odrębnych porządków, które muszą się wzajemnie uzupełniać. Sprawiedliwy porządek w sferze życia społecznego, ekonomicznego i państwowego należy zasadniczo do polityki, podczas gdy chrześcijańska miłość jest odpowiedzią na spotkanie konkretnego człowieka w potrzebie, która dotyka i rani jego człowieczeństwo. Sprawiedliwy porządek, wprowadzany przez działania polityczne, nie zastąpi miłości.

Miłość - caritas - zawsze będzie konieczna - pisze Benedykt xvi - również w najbardziej sprawiedliwej społeczności. Nie ma takiego sprawiedliwego porządku państwowego, który mógłby sprawić, że posługa miłości byłaby zbędna. Kto usiłuje uwolnić się od miłości, będzie gotowy uwolnić się od człowieka jako człowieka. Zawsze będzie istniało cierpienie, które potrzebuje pocieszenia i pomocy. Zawsze będzie samotność. Zawsze będą sytuacje materialnej potrzeby, w których konieczna jest pomoc w duchu konkretnej miłości bliźniego ${ }^{75}$.

Nie należy oczekiwać, że struktury państwowe rozwiążą wszystkie problemy, natomiast możemy oczekiwać, że państwo będzie wspierało te inicjatywy, które stosują metody spontaniczności i bliskości z ludźmi potrzebującymi ${ }^{76}$. Chrześcijańską specyfiką praktykowania miłosierdzia jest jego bezpośredniość: „jest aktualizacją tu i teraz miłości, której człowiek potrzebuje zawsze”77, a także to, że zawsze obejmuje całego człowieka, nie poprzestając na zaspokojeniu

74 Por. P. M.Zulehner, Bóg jest większy od naszego serca. Teologia i duszpasterstwo miłosierdzia, Kraków 2010, s. 83-84.

75 Benedykt XVI, Encyklika Deus caritas est, 28.

${ }^{76}$ „Nie państwo, które ustala i panuje nad wszystkim, jest tym, którego potrzebujemy, ale państwo, które dostrzeże i wesprze, w duchu pomocniczości, inicjatywy podejmowane przez różnorakie siły społeczne, łączące w sobie spontaniczność i bliskość z ludźmi potrzebującymi pomocy”, Benedykt xvi, Encyklika Deus caritas est, 28.

77 Tamże, $31 \mathrm{~b}$. 
potrzeb materialnych dostrzega w człowieku i oferuje mu odpowiednie środki do zaspokojenia potrzeb duchowych, spośród których największą pozostaje zawsze głód Boga.

\section{Uczynki miłosierdzia jako troska o wykluczonych}

Papież Franciszek w swoim społecznym nauczaniu zwraca uwagę, że wraz z rozwojem ekonomicznym, który jest naznaczony niepochamowaną chęcią zysku, gdzie „wszystko poddane jest prawom rywalizacji i prawu silniejszego,

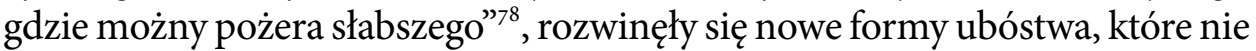
tylko są skutkiem źle funkcjonującej sprawiedliwości społecznej, ale posiadają bardziej zasadniczy charakter. Nie chodzi tylko o to, że niektórym ludziom brakuje elementarnych środków potrzebnych do życia godnego człowieka, ale o to, że są ludzie, którzy nie mają nawet szans na zdobycie owych środków. To ludzie, których papież określa pojęciem „wykluczeni” i stwierdza, że „stanowią większość mieszkańców planety - to miliardy ludzi”79.

Znajdują się oni na peryferiach życia społecznego - to pojęcie, którego często używa Franciszek, myśląc nie tylko o obrzeżach wielkich aglomeracji, które w pewnych regionach świata funkcjonują jako slumsy, ale także o tych, którzy egzystują poza głównym nurtem życia społecznego i ekonomicznego i nie partycypują w żaden sposób w osiągnięciach postępu. Spychani na margines i pogardzani są postrzegani jako nieużyteczni, owszem, nawet jako zagrożenie dla ustalonego porządku, gdyż niesprawiedliwość rodzi przemoc ${ }^{80}$.

Daliśmy początek kulturze „odrzucenia”, którą wręcz się promuje. Nie chodzi już tylko o zjawisko wyzysku i ucisku, ale o coś nowego: przez wykluczenie zraniona jest w samej swej istocie przynależność do społeczeństwa, w którym człowiek żyje, ponieważ nie jesteśmy w nim nawet na samym dole, na peryferiach czy pozbawieni władzy, ale poza nim. Wykluczeni nie są «wyzyskiwani», ale są odrzuceni, są „niepotrzebnymi resztkami”"

78 Franciszek, Adhortacja Evangelii gaudium, 53.

79 Franciszek, Encyklika Laudato si' (24 maja 2015), 49.

so „Gdy społeczność - lokalna, krajowa czy światowa - pozostawia na peryferiach część siebie, nie będzie programów politycznych ani sił porządkowych czy bezpieczeństwa, które mogłyby w sposób nieograniczony zapewnić spokój. Nie będzie tak nie tylko dlatego, że nierówność społeczna prowokuje do gwałtownej reakcji wykluczonych przez system, ale ponieważ system społeczny i ekonomiczny jest niesprawiedliwy u korzeni", Franciszek, Adhortacja Evangelii gaudium, 59.

${ }^{81}$ Franciszek, Adhortacja Evangelii gaudium, 53. 
Zasadniczą biedą, której doświadczają tacy ludzie, jest „brak możliwości”"2 , co jest owocem globalizacji obojętności ${ }^{83}$. Podstawową formą pomocy dla tych ludzi jest stworzenie im równych szans, usunięcie uprzedzeń i docenienie potencjału, jaki tkwi w ludziach ubogich ${ }^{84}$. Znakomitym przykładem takiej pomocy jest opis uzdrowienia przez Jezusa niewidomego (por. J 9, 1-41). Franciszek wyjaśnia najpierw, że problem niewidomego polegał nie tylko na samym braku wzroku. Był on zepchnięty na margines nie tylko z powodu swojego kalectwa, ale - jak stwierdza papież - „ze względu na fałszywe wyobrażenie, zgodnie z którym była to kara Boża. Jezus radykalnie odrzuca ten sposób myślenia - który jest naprawdę bluźnierczy!”. I konkluduje: „Oto dwie przeciwstawne kultury. Kultura spotkania i kultura wykluczenia, kultura

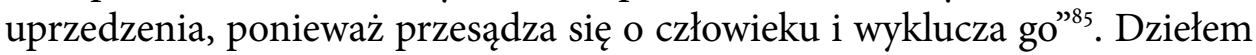
miłosierdzia w tej sytuacji jest przełamanie uprzedzenia wobec nich samych, ich obecnej sytuacji życiowej, zdolności, które posiadają, i „stworzenie równych szans" dla każdego.

W tym kontekście Franciszek przypomina, że pierwszym krokiem w podejmowaniu uczynków miłosierdzia jest dostrzec rzeczywistą biedę, która czasem jest bardzo ukryta i nie afiszuje się ze swoją słabością, albo dostrzec przyczyny biedy tak, aby pomoc nie dotyczyła tylko likwidacji skutków, lecz sięgała do korzeni. Drugi krok to współczucie, oznaczające wewnętrzne utożsamienie się z cierpieniem drugiego człowieka, przeżywaniem go jako swojego.

Nasze zaangażowanie - pisze papież Franciszek - nie polega wyłącznie na działaniach albo na programach promocji i opieki. To, co uruchamia Duch, nie jest przesadnym aktywizmem, ale przede wszystkim uwagą skierowaną na drugiego człowieka, „uważaniem go za jedno z samym sobą”. Ta wrażliwość miłości jest

82 Tamże, 54 .

${ }^{83}$ „Aby utrzymać styl życia wykluczający innych albo żeby móc entuzjazmować się tym egoistycznym ideałem, rozwinęła się globalizacja obojętności. Niemal nie zdając sobie z tego sprawy, stajemy się niezdolni do współczucia wobec krzyku boleści innych, nie płaczemy już wobec dramatu innych ani nie interesuje nas troska o nich, tak jakby odpowiedzialność za to nas nie dotyczyła. Kultura dobrobytu nas znieczula i tracimy spokój, jeśli rynek oferuje coś, czego jeszcze nie kupiliśmy, podczas gdy zrujnowane życie tych wszystkich ludzi z powodu braku szans wydaje nam się zwykłym spektaklem, który nas wcale nie porusza”, Franciszek, Adhortacja Evangelii gaudium, 54 .

${ }_{4}$ Por. Franciszek, Adhortacja Evangelii gaudium, 59.

${ }^{85}$ Franciszek, Od kultury wykluczenia do kultury spotkania, Spotkanie z członkami Apostolskiego Ruchu Niewidomych i Małej Misji dla Głuchoniemych (29 marca 2014). 
początkiem prawdziwego zatroskania o jego osobę i od niej wychodząc, pragnę szukać skutecznie jego dobra. Zakłada to docenianie ubogiego $\mathrm{z}$ jego dobrocią, $\mathrm{z}$ jego sposobem życia, $\mathrm{z}$ jego kulturą, $\mathrm{z}$ jego sposobem przeżywania wiary ${ }^{86}$.

Tak rozumiane współczucie niewiele ma wspólnego z litością, która zawsze proponuje jedynie powierzchowne rozwiązanie i nigdy nie sięga samego rdzenia cierpienia i jego przyczyn.

Konieczność realizowania uczynków miłosierdzia jako wyraźne polecenie Chrystusa była od zawsze obecna w świadomości uczniów Chrystusa i przez wieki stanowiła wewnętrzy imperatyw sumienia, wynikający z samego faktu bycia uczniem Chrystusa. Święty Tomasz wprowadził to przekonanie na poziom ścisłej powinności moralnej, określając zarazem zakres jej obowiązywalności. Pozytywnym skutkiem tego był fakt, że uczynki miłosierdzia były traktowane jak przykazanie zobowiązujące każdego chrześcijanina, tym samym inspirując do podejmowania działań na rzecz biednych, które przybierały różną formę w zależności od zmieniających się warunków społecznych. Ujemną konsekwencją, aczkolwiek niezamierzoną przez Tomasza, było to, że jego rozwiązania mogły być wykorzystywane do zawężania wrażliwości na potrzebujących i ograniczania się do standardowych działań. Współcześnie imperatyw miłosierdzia przekracza tradycyjne granice, każe otwierać się zarówno na nowe przestrzenie biedy, jak też zmusza do szukania nowych form okazywania pomocy. Symboliczne bona superflua przekształcają się w „wyobraźnię miłosierdzia”.

\section{AbstrakT}

\section{Uczynki miłosierdzia względem ciała i duszy. Historia i praktyka}

Wspomaganie biednych i potrzebujących uczynił Kościół ważnym elementem swojego posłannictwa, jako odpowiedź na wyraźny nakaz realizacji przykazania miłości bliźniego dany przez Chrystusa. Obowiązek okazywania czynnej miłości bliźniemu został wyrażony w katechizmowej formule uczynków miłosierdzia co do ciała i co do duszy. Artykuł analizuje zarówno genezę powstania tej formuły, jak również jej historyczną interpretację na przestrzeni wieków.

\footnotetext{
${ }^{86}$ Franciszek, Adhortacja Evangelii gaudium, 199.
} 
Uczynki miłosierdzia co do ciała zostały wyraźnie sformułowane przez samego Chrystusa w kontekście nauki o sądzie ostatecznym, zapisanej w Ewangelii św. Mateusza 25, 31-40, natomiast uczynki co do duszy znajdują swoje biblijne uzasadnienie w różnych miejscach Ewangelii. W III wieku Orygenes w duchu egzegezy alegorycznej interpretował uczynki miłosierdzia wymienione w Ewangelii Mateusza także jako wezwanie do pomocy w duchowych potrzebach człowieka, a za nim na Zachodzie czynił tak św. Augustyn. W ten sposób stopniowo rodziła się lista siedmiu uczynków co do duszy.

Klasyczną interpretację moralną uczynków miłosierdzia podał św. Tomasz z Akwinu, ustalając, w jakich warunkach są one ścisłą powinnością moralną. W późniejszym okresie w praktykowaniu miłosierdzia podkreślano takie elementy jak: osobiste doświadczenie Bożego miłosierdzia jako wezwanie do pomocy innym (św. Faustyna), dowartościowanie człowieka w jego godności (św. Jan Paweł II) oraz w ostatnim czasie troska o ludzi wykluczonych, czyli pozbawionych możliwości własnego rozwoju (papież Franciszek).

\section{SŁOWA KLUCZOWE}

miłosierdzie, uczynki miłosierdzia, katechizm, caritas, jałmużna, biedni, działalność charytatywna, św. Tomasz z Akwinu, św. Faustyna, św. Jan Paweł II

\section{Abstract}

The works of mercy toward the body and soul. History and practice The Church made assisting the poor and needy an important part of its mission, as a response to an explicit command to enact the commandment to love one's neighbor given by Christ. The obligation to show an active love of neighbor is expressed in the catechism formula of works of mercy toward the body and soul. The article analyzes both the genesis of this formula, as well as its historical interpretation over the centuries.

The corporal works of mercy have been clearly stated by Christ Himself in the context of the teaching of the last judgment recorded in the Gospel of Matthew 25:31-40, however the spiritual works of mercy find their biblical justification in different places of the Gospels. In III century Origen in the spirit of allegorical exegesis interpreted the works of mercy mentioned in the Gospel of Matthew also as a call to help in the spiritual needs of man, and after him St. Augustine in the West. In this way, gradually the list of seven works of mercy concerning the soul was established.

St. Thomas Aquinas gave us the classical moral interpretation of the acts of mercy, establishing the conditions under which they are a strict moral obligation. I the later 
period in the practice of charity stressed the elements such as: a personal experience of God's mercy as a call to help others (St. Faustina), valuing man in his dignity (St. John Paul II) and recentely a concern for people excluded or deprived of opportunities of self-development (Pope Francis).

\section{KEYWORDS}

divine mercy, mercy to the poor, alms, catechism, charity parochial, St. Faustina, St. John Paul II, Pope Francis

\section{BiBLIOGRAFIA}

\section{Źródła}

Benedykt xvi, Encyklika Deus caritas est (25 grudnia 2005).

Franciszek, Adhortacja Evangelii gaudium (24 listopada 2013).

Franciszek, Bulla Misericordiae vultus (11 kwietnia 2015).

Franciszek, Encyklika Laudato si' (24 maja 2015).

Jan Paweł II, Dar Boży dla naszych czasów, homilia na mszy kanonizacyjnej bł. Faustyny Kowalskiej (30 kwietnia 2000).

Jan Paweł II, Encyklika Dives in misericordia (30 listopada 1980).

Jan Paweł II, Orędzie na Wielki Post 1983.

Jan Paweł II, Orędzie na Wielki Post 1984.

Jan Paweł II, Przekroczyć próg nadziei, Lublin 1994.

Pius XI, Encyklika Quadragesimo anno (15 maja 1931).

\section{Literatura}

Bądźcie miłosierni jak Ojciec wasz jest miłosierny (Łk 6, 36), red. T. M. Dąbek, Kraków 2002.

Degórski B., Uczynki miłosierdzia w świetle starożytnych reguł mniszych, „Vox Patrum” 1996, z. 30-31, s. 259-274.

Kowalska F., Dzienniczek, Kraków-Stockbridge-Rzym 1981.

Noldin H., Summa theologice moralis, vol. 2: De proeceptis, Insbruck 1955.

Noye I., Miséricorde, [w:] Dictionnaire de spiritualité, vol. 10, part. 2, kol. 1328-1349.

Ryłko T., Bogaci w miłosierdzie, Kraków 1995.

Sobkowiak J. A., Nowe uczynki miłosierdzia, [w:] Abyśmy się stali synami Bożymi, Warszawa 2011, s. 217-232.

Strzeszewski C., „Bona superflua” w etyce społecznej św. Tomasza z Akwinu, „Roczniki Filozoficzne" 8 (1960) z. 2, s. 53-59. 
Szkoła miłosierdzia świętej Faustyny i Jana Pawła II, red. F. Ślusarczyk, Kraków 2008. Tomasz z Akwinu, Summa theologio.

Wejman H., Personalistyczna koncepcja miłosierdzia, „Teologia i moralność” 2 (2007), S. 210-211.

Zulehner P. M., Bóg jest większy od naszego serca. Teologia i duszpasterstwo miłosierdzia, Kraków 2010. 